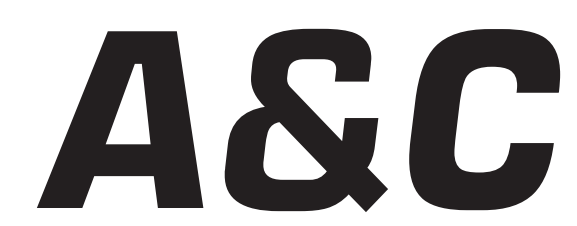

Revista de Direito Administrativo \& Constitucional

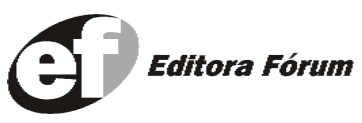

A\&C R. de Dir. Administrativo e Constitucional, Belo Horizonte, ano 5, n. 20, p. 1-255, abr.jun. 2005 


\section{A\&C REVISTA DE DIREITO ADMINISTRATIVO E CONSTITUCIONAL}

\section{IPDA}

Instituto Paranaense

de Direito Administrativo

Direção Geral

Romeu Felipe Bacellar Filho

Direção Editorial

Paulo Roberto Ferreira Motta

Direção Executiva

Emerson Gabardo

Conselho de Redação

Edgar Chiuratto Guimarães

Adriana da Costa Ricardo Schier

Célio Heitor Guimarães

Conselho Editorial

Adilson Abreu Dallari

Alice Gonzáles Borges

Carlos Ari Sundfeld

Carlos Ayres Britto

Carlos Delpiazzo

Cármen Lúcia Antunes Rocha

Celso Antônio Bandeira de Mello

Clèmerson Merlin Clève

Clóvis Beznos

Enrique Silva Cimma

Eros Roberto Grau

Fabrício Motta

Guilhermo Andrés Muñoz (in memoriam)

Jaime Rodríguez-Arana Muñoz

Jorge Luís Salomoni
José Carlos Abraão
José Eduardo Martins Cardoso

José Luís Said

José Mario Serrate Paz

Juan Pablo Cajarville Peruffo

Juarez Freitas

Julio Rodolfo Comadira

Luís Enrique Chase Plate

Lúcia Valle Figueiredo

Manoel de Oliveira Franco Sobrinho

(in memoriam)

Marçal Justen Filho

Marcelo Figueiredo

Márcio Cammarosano

Maria Cristina Cesar de Oliveira
Nelson Figueiredo

Odilon Borges Junior

Pascual Caiella

Paulo Eduardo Garrido Modesto

Paulo Henrique Blasi

Paulo Neves de Carvalho (in memoriam)

Paulo Ricardo Schier

Pedro Paulo de Almeida Dutra

Regina Maria Macedo Nery Ferrari

Rogério Gesta Leal

Rolando Pantoja Bauzá

Sérgio Ferraz

Valmir Pontes Filho

Yara Stropa

Weida Zancaner

\footnotetext{
A246 A\&C Revista de Direito Administrativo e Constitucional. ano 3, n. 11, jan./mar. 2003. Belo Horizonte: Fórum, 2003.

Trimestral

ano 1, n.1, 1999 até ano 2, n.10, 2002 publicada pela Editora Juruá em Curitiba

ISSN: 1516-3210

1. Direito Administrativo. 2. Direito Constitucional. I. Fórum.
}

CDD: 342 CDU: 33.342

(c) Editora Fórum Ltda. 2005

Todos os direitos reservados. É proibida a reprodução total ou parcial, de qualquer forma ou por qualquer meio eletrônico ou mecânico, inclusive através de processos xerográficos, de fotocópias ou de gravação, sem permissão por escrito do possuidor dos direitos de cópias (Lei $n^{\circ}$ 9.610, de 19.02.1998).

Editora Fórum Ltda

Av. Afonso Pena, 2770 - 15\%16ªndar - Funcionários

CEP 30130-007 - Belo Horizonte/MG - Brasil

Tel.: 08007043737

Internet: www.editoraforum.com.br

e-mail: editoraforum@editoraforum.com.br
Editor responsável: Luís Cláudio Rodrigues Ferreira Projeto gráfico e diagramação: Luis Alberto Pimenta Revisora: Olga M. A. Sousa

Pesquisa jurídica: Fátima Ribeiro - OAB/MG 74868

Bibliotecária: Nilcéia Lage de Medeiros

CRB 1545/MG 6a região

Os conceitos e opiniões expressas nos trabalhos assinados são de responsabilidade exclusiva de seus autores.

Impressa no Brasil / Printed in Brazil

Distribuída em todo Território Nacional 


\title{
Participação Administrativa
}

\author{
Gustavo Henrique Justino de Oliveira \\ Doutor em Direito do Estado pela USP. Professor no Instituto de Direito Romeu Felipe Bacellar. \\ Procurador do Estado do Paraná. Advogado e Consultor em Curitiba
}

Sumário: 1 Introdução - 2 Cidadania e participação - 3 Democracia representativa e democracia participativa - 4 Participação administrativa 4.1 Conceituação - 4.2 A problemática da participação administrativa - 4.3 Participação administrativa e participação procedimental - 4.3.1 Momentos e efeitos da participação procedimental - 4.4 Legitimidade pelo procedimento e legitimidade pela participação - 4.5 Participação, descentralização e negociação - 4.6 A participação gerencial - 5 Considerações finais - Bibliografia

\section{Introdução}

Nas duas últimas décadas do séc. XX espraiaram-se os clamores por uma premente readequação do modo de ser e de atuar do Estado, como forma de superação dos efeitos adversos ocasionados pelo aprofundamento da crise do modelo providencialista. ${ }^{1}$

Independentemente de serem países dotados de economias desenvolvidas ou em desenvolvimento, neles proliferou a criação de Comissões Especiais ou Ministérios, incumbidos de realizarem avaliações, estudos, relatórios, programas e projetos, inseridos em processos denominados de Reforma ou Modernização de Estado.

Nesse contexto de transformação, o objetivo principal era o de encontrar respostas adequadas às crescentes demandas tendentes a redefinir os fins e o alcance do Estado, reestipular suas tarefas e redesenhar sua organização político-institucional e administrativa. Programas de Reforma ou Modernização de Estado não somente foram incorporados, mas passaram a ser a tônica nas Agendas de Governo em todo o mundo, sobretudo por meio da denominação Reforma Administrativa.

Contudo, é preciso ressaltar que Reforma Administrativa exprime

\footnotetext{
1 Embora seja possível identificar variações do denominado modelo providencialista (sobretudo entre países dotados de economias mais desenvolvidas) a nota caracterizante do gênero Estado do Bem-Estar Social consiste, indubitavelmente, no intervencionismo estatal nas atividades econômicas, encarado como a forma mais adequada de proporcionar o desenvolvimento econômico e social da população. Após a Segunda Guerra Mundial e apoiadas nas fórmulas elaboradas por John M. Keynes, as políticas econômicas passaram a estabelecer os principais traços da condução dos assuntos econômicos pelo Estado (planejamento), estimulando inclusive sua direta atuação na economia (estatização). Assim, a intervenção do Estado na economia era justificada pelo fim de promover-se o bem-estar populacional através da socialização dos investimentos, pois "se o capital privado decide não investir, é o Estado quem deve investir com o objetivo de reativar a economia" (RODRÍGUEZ GUERRA, Jorge. Capitalismo Flexible y Estado de Bienestar. Granada: Comares, 2001. p. 39.).
} 
uma das vertentes da Reforma do Estado, representando um conjunto de medidas direcionadas a modificar as estruturas, organização, funcionamento, tarefas e instrumentos da Administração Pública, com a finalidade de melhor capacitá-la para servir aos fins do Estado e aos interesses da sociedade. Para Diogo Freitas do Amaral trata-se de "um conjunto sistemático de providências destinadas a melhorar a Administração Pública de um dado país, por forma a torná-la, por um lado mais eficiente na prossecução dos seus fins e, por outro, mais coerente com os princípios que a regem". ${ }^{2}$ Enfatiza Diogo de Figueiredo Moreira Neto que uma reforma administrativa deve anteceder às demais reformas que integram o panorama da Reforma de Estado, e constitui-se na mais importante delas, "pois passa a ser o mais decisivo instrumento para levar a cabo todos os demais aspectos da reforma de Estado". ${ }^{3}$

A generalização das causas da transformação e a similitude dos problemas enfrentados pelos países desenvolvidos foram fatores preponderantes no alastramento do fenômeno reformador do Estado e, por extensão, das reformas da Administração Pública. No entanto, ao contrário do que poder-se-ia supor, tais semelhanças não motivaram o surgimento e a adoção de soluções homogêneas.

Tal assertiva não implica desconsiderar as inovações advindas dos movimentos reformadores e modernizadores ocorridos em outros países, pois efetivamente há um mínimo denominador comum no que tange às transformações ocorridas a partir dos recentes Programas de Reforma e Modernização de Estado e da Administração Pública.

Manuel Villoria Mendieta elenca propostas de promoção de um ajuste fiscal para a eliminação do déficit público; privatizações e desregulamentações; busca da qualidade na prestação dos serviços públicos com a inevitável orientação ao cliente; desconcentração e descentralização; maior participação das organizações não-governamentais na gestão dos serviços; tentativas de redução do hiperpositivismo jurídico; criação de instrumentos de combate à corrupção. ${ }^{4}$

Odete Medauar lista maior sensibilidade quanto aos direitos dos cidadãos, que implica valorização do cidadão; identificação e aplicação 2 AMARAL, Diogo Freitas do. Curso de Direito Administrativo. 2. ed. 5. reimp. Coimbra: Almedina, 2001. v. 1, p. 199.

3 MOREIRA NETO, Diogo de Figueiredo. Apontamentos sobre a Reforma Administrativa. Rio de Janeiro: Renovar, 1999. p. 17. O autor vislumbra cinco linhas de transformação que permeariam a cruzada por uma nova configuração da Administração Pública: (i) passar dos modelos tutelares [de Estado] aos instrumentais; (ii) dos modelos burocráticos aos gerenciais; (iii) dos modelos processualizados aos de resultados; (iv) dos modelos voltados à eficácia aos voltados à eficiência; e (v) dos modelos que acentuam a ética intencional àqueles que destacam a ética de resultados (Ibid., p. 18.).

4 VILLORIA MENDIETA, Manuel. La Modernización de la Administración como Instrumento al Servicio de la Democracia. Madrid: Inap, 1996. p. 17. 
de índices de qualidade, de padrões de produtividade e avaliação da satisfação dos usuários de serviços públicos; quebra total ou parcial de monopólios; regulação de setores privatizados e de atividades sensíveis, sobretudo mediante agências reguladoras ou autoridades independentes; estímulo à concorrência nos serviços públicos; ampliação das parcerias público-privado; forte descentralização; simplificação de procedimentos; deslegificação, entendida como maior atribuição de poder normativo à cúpula do Poder Executivo, a agências reguladoras ou ainda a entes locais e ao próprio setor a ser regulado (auto-regulação total ou parcial); controle de gestão e incentivo à participação dos cidadãos isolados ou associados na tomada de decisões. ${ }^{5}$

A partir desse quadro em contínua mutação, concorda-se com afirmação de Norberto Bobbio registrada em obra publicada em 1985, para quem "o Estado de hoje está muito mais propenso a exercer uma função de mediador e de garante, mais do que a de detentor do poder de império". ${ }^{6}$

Por seu turno, em clássico artigo publicado em 1887 intitulado $O$ Estudo da Administração, Woodrow Wilson alertava que "a idéia do Estado é a consciência da administração". ${ }^{7}$ Complementando sua afirmação, aduziu o autor que "observando-se, cada dia, os novos encargos que o Estado é compelido a assumir, cumpre ao mesmo tempo distinguir claramente como lhe caberá desincumbir-se dêles". ${ }^{8}$ [sem grifo no original]

José Ortiz Díaz esclarece que atualmente, e sobretudo na doutrina alemã, "a denominação 'Estado Constitucional' é utilizada para identificar e tipificar um determinado modelo de Estado em que a Constituição alcança 'primazia' qualificadora e um caráter 'prevalente' em face do todo e em relação aos fins estatais". ${ }^{9}$ Pondera que no estabelecimento desses fins estatais há a necessidade de conciliar-se a dimensão subjetiva dos direitos fundamentais com o caráter objetivo dos fins do Estado.

No cenário do Estado constitucional, acrescenta José Ortiz Díaz que "os genéricos e clássicos fins estatais (...) concretizam-se em grande parte (...) na satisfação efetiva dos direitos fundamentais da pessoa, principalmente

5 MEDAUAR, Odete. O Direito Administrativo em Evolução. 2. ed. São Paulo: Revista dos Tribunais, 2003. p. 133-134.

6 BOBBIO, Norberto. Estado, Governo e Sociedade. 4. ed. Rio de Janeiro: Paz e Terra, 1987. p. 26.

7 WILSON, Woodrow. O Estudo da Administração. Cadernos de Administração Pública, Rio de Janeiro, n. 16, p. 1-35, 1955. p. 16.

$8 \mathrm{Id}$.

9 ORTIZ DIAS, José. El Horizonte de las Administraciones Públicas en el Cambio de Siglo: Algunas Consideraciones de Cara al año 2000. In: SOSA WAGNER, Francisco (Coord.) El Derecho Administrativo en el Umbral del Siglo XXI: Homenage al Profesor Dr. D. Ramón Martín Mateo, Valencia: Tirant lo Blanch, 2000. t. 1, p. 63-117. p. 70-71.

A \& C R. de Dir. Administrativo e Constitucional, Belo Horizonte, ano 5, n. 20, p. 167-194, abr./jun. 2005 
a cargo das Administrações Públicas,.....${ }^{10}$ [sem grifo no original] E explicita:

A clássica, indeterminada e universalista função dos fins estatais como o bem comum, o "interesse público", as necessidades públicas, concretizam-se na atualidade (em sua grande maioria) na satisfação dos direitos humanos e nas liberdades positivas da pessoa. Objetivos primordiais das Administrações Públicas em nosso tempo deve ser precisamente a satisfação dos direitos e liberdades fundamentais, sendo missão do Direito Administrativo garantir efetivamente essa satisfação. ${ }^{11}$

Sob esse enfoque, Manuel Villaroria Mendieta põe em relevo uma nova configuração da função administrativa, propondo readequações na estrutura e gestão administrativas, notadamente voltadas à valorização do processo de diálogo:

A Administração não pode esquivar-se de seu papel central de sustentação do sistema. A ela cabe, goste disso ou não, a responsabilidade final dos grandes fracassos sociais (DE LEÓN, 1989). Também é sua responsabilidade gerar uma rede público-privada que confira respostas às necessidades da sociedade como um todo. Ela é a responsável pelo processo de diálogo, fazendo com que o mesmo atenda as garantias de igualdade para todos os implicados em virtude da aplicação de determinadas políticas. Tudo isso demanda responsabilidade, não hierarquias; centralidade, não monopólio. Governar será, a partir de agora, configurar e manter um adequado espaço de co-direção e equilíbrio entre as partes implicadas em cada política (KOOIMAN, 1993). Como alcançar isso sem hierarquias, como concretizar tal objetivo sem autoridade, são perguntas a procura de respostas (WILDAVSKY), ainda que determinados dados e práticas apontem para a resultados positivos. ${ }^{12}$

Em trabalho que exorta a participação dos cidadãos na Administração pública, João Baptista Machado ressalta que a satisfação dos interesses e necessidades vitais é mediatizada pela máquina administrativa, razão pela qual um meio apropriado aos cidadãos para lutarem por tais interesses é a sua atuação sobre o funcionamento desta máquina. ${ }^{13}$

Com efeito, porque cumpre aprioristicamente à organização administrativa estatal conferir respostas às demandas da sociedade, afigura-se correto sustentar ser a Administração Pública uma interface entre o Estado e a sociedade. Sua principal função é a de receber os influxos e estímulos da

\footnotetext{
10 lbid., p. 70

$11 \mathrm{ld}$.

12 VILLORIA MENDIETA, Manuel. La Modernización de la Administración como Instrumento al Servicio de la Democracia, 1996. p. 381.

${ }^{13}$ MACHADO, João Baptista. Participação e Descentralização: Democratização e Neutralidade na Constituição de 76. Coimbra: Almedina, 1982. p. 38
} 
sociedade, rapidamente decodificá-los e prontamente oferecer respostas aptas à satisfação das necessidades que se apresentam no cenário social, seja no campo da regulação, seja no campo da ação.

De outro lado, na esfera administrativa o consenso entre Administração pública, cidadãos e sociedade civil — ou ao menos as decisões administrativas previamente negociadas — resultam do exercício do direito de participação na Administração pública.

Dessarte, espera-se que o Estado contemporâneo aguce sua capacidade de agente conciliador dos conflitos imanentes à sociedade policêntrica da atualidade, não somente estabelecendo canais de participação e interlocução com seus representantes, mas igualmente criando vínculos, acordos, alianças e parcerias com as entidades empresariais e sociais.

Nesse cenário, exsurge o fenômeno da participação administrativa, o qual configura uma das linhas de evolução da Administração pública contemporânea. Para Odete Medauar, participação administrativa referese (i) à identificação do interesse público de modo compartilhado com a população, (ii) ao decréscimo da discricionariedade, (iii) atenuação da unilateralidade na formação dos atos administrativos e (iv) às práticas contratuais baseadas no consenso, negociação e conciliação de interesses. ${ }^{14}$

Como premissas ao enfrentamento do tema proposto, cumpre apreciar o sentido contemporâneo de cidadania e as noções de democracia representativa e democracia participativa.

\section{Cidadania e participação}

A consagração da noção de Estado de direito por um Texto Constitucional tem, originalmente, dupla finalidade: a imposição de limites ao exercício do poder estatal e a criação de uma autêntica garantia constitucional aos cidadãos.

No que tange à democracia, mesmo sendo difícil conquistar a unanimidade na determinação precisa de seus contornos elementares, Norberto Bobbio alude à existência de uma definição mínima. O autor assinala a possibilidade de caracterizá-la como "um conjunto de regras (primárias ou fundamentais) que estabelecem quem está autorizado a tomar as decisões coletivas e com quais procedimentos". ${ }^{15}$ A democracia estaria, assim, essencialmente relacionada à formação e atuação do governo.

Da concepção de democracia extrai-se uma outra noção: a de legiti-

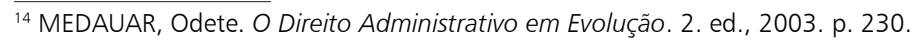

A \& C R. de Dir. Administrativo e Constitucional, Belo Horizonte, ano 5, n. 20, p. 167-194, abr.jun. 2005 
midade, concebida por Diogo de Figueiredo Moreira Neto como "submissão do poder estatal à percepção das necessidades e dos interesses do grupo nacional que lhe dá existência". ${ }^{16}$

José Joaquim Gomes Canotilho aduz que a consagração constitucional da noção de democracia (Estado Democrático de Direito) tem a finalidade de erigi-la a um autêntico princípio informador do Estado e da sociedade, e assevera que o sentido constitucional desse princípio é a democratização da democracia, ou seja, a condução e a propagação do ideal democrático para além das fronteiras do território político. ${ }^{17}$

Para Odete Medauar, "a preocupação com a democracia política leva, muitas vezes, ao esquecimento da democracia administrativa, quando, na verdade, esta deveria ser o reflexo necessário da primeira". ${ }^{18}$ [sem grifo no original]

É o que José Joaquim Gomes Canotilho denomina democratização da administração, a qual pode manifestar-se (i) na substituição das estruturas hierárquico-autoritárias por formas de deliberação colegial, (ii) introdução do voto na seleção das pessoas a quem foram confiados cargos de direção individual, (iii) participação paritária de todos os elementos que exercem a sua atividade em determinados setores da Administração, (iv) transparência ou publicidade do processo administrativo e (v) gestão participada, que consiste na participação dos cidadãos por meio de organizações populares de base e de outras formas de representação na gestão da Administração pública. ${ }^{19}$

Assim, conforme ressaltou-se em trabalho anterior, não é possível

${ }_{15}$ BOBBIO, Norberto.O Futuro da Democracia: uma Defesa das Regras do Jogo. 5. ed. Rio de Janeiro: Paz e Terra, 1992. p. 18. Cf. ainda BOBBIO, Norberto et al. Crisis de la Democracia. Barcelona: Editorial Ariel, 1985. Sobre as teorias da democracia, cf. SAMPAIO, José Adércio Leite. Democracia, Constituição e Realidade. Revista Latino-americana de Estudos Constitucionais, Belo Horizonte, n.1, p. 741-823, jan./jun. 2003.

${ }^{16}$ MOREIRA NETO, Diogo de Figueiredo. Direito da Participação Política. Rio de Janeiro: Renovar, 1992. p. 65. Explicita o autor que o controle de legalidade advém da configuração do Estado de direito. Por sua vez, o Estado de direito democrático institucionalizaria o controle de legitimidade (Id.). Para Paulo Bonavides, em um regime democrático a legalidade "é o seu enquadramento nos moldes de uma constituição observada e praticada; sua legitimidade será sempre o poder contido naquela constituição, exercendo-se de conformidade com as crenças, os valores e os princípios da ideologia dominante, no caso a ideologia democrática" (BONAVIDES, Paulo. Ciência Política. 10. ed. São Paulo: Malheiros, 2003. p. 112.). Sobre legitimidade no Estado contemporâneo, cf. GABARDO, Emerson. Eficiência e Legitimidade do Estado: uma Análise das Estruturas Simbólicas do Direito Político. Barueri: Manole, 2003.

${ }^{17}$ CANOTILHO, José Joaquim Gomes. Direito Constitucional. 5. ed. 2. reimp. Coimbra: Almedina, 1992. p. 421. Para Regina Maria Macedo Nery FERRARI, "a Democracia corporifica-se como um processo dinâmico, próprio de uma sociedade que aceita o desenvolvimento do cidadão, proporcionando sua participação no processo político em condições de igualdade, o que se reflete no campo econômico, político, social e jurídico" (FERRARI, Regina Maria Macedo Nery. Participação Democrática: Audiências Públicas. In: CUNHA, Sérgio Sérvulo; GRAU, Eros Roberto (orgs.) Estudos de Direito Constitucional em Homenagem a José Afonso da Silva. São Paulo: Malheiros, 2003. p. 325-351. p. 331.).

${ }^{18}$ MEDAUAR, Odete. Administração Pública ainda sem Democracia. Problemas Brasileiros, São Paulo, a. 23, n. 256, p. 37-53., mar./abr. 1986. p. 38.

A \& C R. de Dir. Administrativo e Constitucional, Belo Horizonte, ano 5, n. 20, p. 167-194, abr.jun. 2005 
deixar de notar que o Texto Constitucional Pátrio, em diversos momentos, "pautou o caminho para uma maior participação dos cidadãos na esfera administrativa. Em face disso, teve início no Brasil a real democratização administrativa, a ser implementada por intermédio da participação popular na Administração pública...”..$^{20}$ [sem grifo no original]

Dotada de fortes bases históricas, cidadania manifesta o vínculo do indivíduo com o Estado, e portanto, pode ser entendido como "um círculo de capacidade conferido pelo Estado aos cidadãos". ${ }^{21}$ Seu conteúdo foi forjado por meio de lutas, ${ }^{22}$ as quais culminaram em drástica mudança do eixo das relações entre Estado e indivíduo. De uma perspectiva unidimensional Estado-súdito (o indivíduo não era possuidor de direitos frente ao Estado, mas unicamente de deveres para com o Estado), passou-se a uma perspectiva bidimensional Estado-cidadão (direitos e deveres originados do vínculo da cidadania destinam-se tanto ao Estado quanto aos indivíduos). Contudo, a cidadania foi e continua a ser objeto de transformações, razão do contínuo aprofundamento de seu conteúdo e extensão de seu alcance. ${ }^{23}$

\footnotetext{
${ }^{19}$ CANOTILHO, José Joaquim Gomes. Direito Constitucional. 5. ed. 2. reimp., 1992. p. 433. O tema da democracia administrativa suscita a preocupação com o reforço das garantias de determinados direitos fundamentais, pela via da participação dos cidadãos nas organizações e nos procedimentos. Nas palavras de José Joaquim Gomes CANOTILHO, "certos direitos fundamentais adquiriam maior consistência se os próprios cidadãos participassem nas estruturas de decisão" (Ibid., p. 558.). Para o autor, "as condições reais em que se desenvolve a eficácia de um direito fundamental apontam para a necessidade de a lei criar estruturas organizatórias funcionalmente efectivantes desse direito" (Ibid., p. 652.). Miguel Sanchez Moron faz alusão a manifestações participativas "institucionalizadas e juridicamente reguladas" (SANCHEZ MORON, Miguel. Espagne. In: DELPEREE, Francis (Org.). Citoyen et Administration. Bruxelas: Bruylant, 1985. p. 6394. p. 69.). No Brasil, participação regulada ocorreria, por exemplo, nos termos do inc. VI do art. 206 da Lei Maior, preceito que estabelece como um dos princípios constitucionais do ensino, a "gestão democrática do ensino público, na forma da lei".

20 OLIVEIRA, Gustavo Henrique Justino de. As Audiências Públicas e o Processo Administrativo Brasileiro. Revista de Direito Administrativo, Rio de Janeiro, n. 209, p. 153-167, jul./set. 1997. p. 156. Importa registrar que democracia, participação e processo são fenômenos indissociáveis. Elio Fazzalari afirma que o esquema processual "seria a forma em que se realiza também, no plano técnico-jurídico, o jogo da democracia" (FAZZALARI, Elio. Processo: Teoria Generale. In: NOVISSIMO Digesto Italiano, s.I.: s.n., 1966, v. 13, p. 1.074.). Enfatiza Marcelo Caetano que mediante o processo "se traçam as regras que há de seguir a formação, a manifestação e a execução da vontade dos órgãos administrativos assegurando-se a participação conveniente e justa dos membros da coletividade" (CAETANO, Marcelo. Tendências do Direito Administrativo Europeu. Revista de Direito Público, São Paulo, n. 01, p. 25-39, jul./set. 1967. p. 32-33.).

${ }^{21}$ BONAVIDES, Paulo. Ciência Política. 10. ed., 2003. p. 77. Observa-se que a cidadania é um dos fundamentos do Estado Brasileiro, nos termos do inc. II do art. $1^{\circ}$ da Constituição da República. Manoel Gonçalves Ferreira Filho indica que "a nova Constituição brasileira quer apontar a indispensabilidade da participação popular na tomada das decisões políticas. O povo brasileiro deve ser composto de cidadãos, participantes ativos do exercício do poder democrático, não de súditos de qualquer poder, mesmo democrático" (FERREIRA FILHO, Manoel Gonçalves. Comentários à Constituição Brasileira de 1988. 3. ed. São Paulo: Saraiva, 2000. v. 1. p. 19.).

22 Dos confrontos aludidos, resultaram documentos que registraram as conquistas do cidadão frente ao Estado, constituindo-se nas bases do conceito da cidadania. Entre eles, há a precedência da Declaração de direitos da Virgínia (16 jun. 1776) e a Declaração dos direitos do homem e do cidadão (26 ago. 1789). Cf. MIRANDA, Jorge. Textos Históricos do Direito Constitucional. 2. ed. Lisboa: Imprensa Nacional, 1990. p. 31 -
} 
Fábio Konder Comparato, traçando a evolução histórica de seu conceito, distingue três etapas da cidadania: (i) a cidadania na civilização greco-romana, (ii) a cidadania individualista do Estado liberal e (iii) a nova cidadania no Estado social. Com relação a nova cidadania, o autor destaca que sua noção elementar reside "em fazer com que o povo se torne parte principal do processo de seu desenvolvimento e promoção: é a idéia de participação" ${ }^{24}$ [sem grifo no original] E segundo o autor, tal participação há de instaurar-se em cinco níveis: (i) na distribuição dos bens, materiais e imateriais, indispensáveis a uma existência socialmente digna, (ii) na proteção dos interesses difusos ou transindividuais, (iii) no controle do poder político, (iv) na administração da coisa pública e (v) na proteção dos interesses transnacionais.

E no que tange à participação popular na administração da coisa pública, cabe transcrever as considerações de Fábio Konder Comparato:

A relevância da atuação administrativa do Estado social é um fato sobejamente conhecido. Convém, no entanto, advertir para a falsa dicotomia que se procura hoje inculcar, no tocante à distribuição eqüitativa do bem-estar social, entre o estatismo e o privatismo. O princípio da participação popular permite evitar esses extremos, introduzindo uma linha de ação mais democrática na administração da coisa pública. ${ }^{25}$

Eis a figura do cidadão que manifesta sua vontade em fazer parte de procedimentos passíveis de culminar em decisões estatais que afetem direitos seus, não somente de natureza individual, mas de ordem coletiva ou difusa. É o cidadão consciente de seus direitos civis, políticos e sociais (porque bem informado), e que deseja tomar a palavra e expressar sua opinião nos assuntos relativos à condução das atividades públicas. É o cidadão responsável, conhecedor de seu compromisso social de intervir na esfera estatal, visando com que as decisões dela emanadas possam ajustar-se o mais possível com a realidade social. É o cidadão cooperador, que almeja

\footnotetext{
${ }^{23} \mathrm{O}$ dinamismo e evolucionismo imanentes à cidadania são orientados principalmente pelo vetor democrático, e por isso concorda-se com Jaime PINSKY, para quem cidadania em sua acepção mais ampla é a "expressão concreta do exercício da democracia" (PINSKY, Jaime. Introdução. In: PINSKY, Carla Bassanezi; PINSKY, Jaime (Org.). História da Cidadania. São Paulo: Contexto, 2003. p. 9-13. p. 10.). Liszt VIEIRA assevera que "a cidadania, definida pelos princípios da democracia, constitui-se na criação de espaços sociais de luta (movimentos sociais) e na definição de instituições permanentes para a expressão política (partidos, órgãos públicos), significando necessariamente conquista e consolidação social e política" (VIEIRA, Liszt. Cidadania e Globalização. 6. ed. Rio de Janeiro: Record, 2002. p. 40.).

${ }^{24}$ COMPARATO, Fábio Konder. A Nova Cidadania. In: Direito Público: Estudos e Pareceres. São Paulo: Saraiva, 1996 , p. 3-24. p. 10

25 Ibid., p. 19
}

A \& C R. de Dir. Administrativo e Constitucional, Belo Horizonte, ano 5, n. 20, p. 167-194, abr.jun. 2005 
não ser visto como intruso ou estranho na organização administrativa, mas como o seu principal colaborador. Enfim, é o cidadão participador, que assume posturas pró-ativas perante uma Administração pública que deve agir em proveito dos cidadãos e de toda a sociedade. ${ }^{26}$

Clémerson Merlin Clève, enumera cinco qualificativos do vocábulo cidadão, ${ }^{27}$ centralizando sua análise na figura do cidadão propriamente participante, ou seja, aquele que se insere na esfera decisória da Administração Pública. Para o autor, a participação do cidadão na esfera estatal é uma aplicação de mecanismos de democracia direta no âmbito das ações estatais:

A questão da democracia não pode ser posta apenas em termos de representatividade. Não há dúvida que em Estados como os modernos não há lugar para a prescindibilidade da representação política. Os Estados modernos, quando democráticos, reclamam pela técnica da representação popular. A nação, detentora da vontade geral, fala pela voz de seus representantes eleitos. Mas a cidadania não se resume na possibilidade de manifestar-se, periodicamente, por meio de eleições para o legislativo e para o executivo. A cidadania vem exigindo a reformulação do conceito de democracia, radicalizando, até, uma tendência, que vem de longa data. Tendência endereçada à adoção de técnicas diretas de participação democrática. Vivemos, hoje, um momento em que se procura somar a técnica necessária da democracia representativa com as vantagens oferecidas pela democracia direta. Abre-se espaço, então, para o cidadão atuar, direta e indiretamente, no território estatal. ${ }^{28}$

A concepção acima aludida corresponde à noção de democracia participativa, entendida por José Joaquim Gomes Canotilho como "a formação da vontade política de 'baixo para cima', num processo de estrutura de decisões com a participação de todos os cidadãos”. ${ }^{29}$ Para o autor, a noção compreenderia um sentido amplo e um sentido restrito. O primeiro significaria "a participação através do voto, de acordo com os processos e formas da democracia representativa"; ${ }^{30}$ o segundo, traduziria "uma forma mais alargada do concurso dos cidadãos para a tomada de decisões, muitas vezes de forma directa e não convencional". ${ }^{31}$

É o tema que será analisado a seguir, relacionando-o com a demo-

\footnotetext{
${ }^{26}$ Cf. DELPEREE, Francis (Org.). Citoyen et Administration. Bruxelas: Bruylant, 1985 e NIGRO, Mario. II nodo della Partecipazione. Rivista Trimestrale di Diritto e Procedura Civile, Milão, a. 34, n. 1, p. 225-236, mar. 1980, entre outros.

27 Seriam eles o cidadão eleitor, o agente do poder, o colaborador (gestão privada de interesses públicos), o seduzido e o censor. Cf. CLÈVE, Clèmerson Merlin. O Cidadão, a Administração Pública e a Nova Constituição. Revista de Informação Legislativa, Brasília, a. 27, n. 106, p. 81-98, abr./jun. 1990.

28 Ibid., p. 82-83.

${ }^{29}$ CANOTILHO, José Joaquim Gomes. Direito Constitucional. 5. ed. 2. reimp., 1992. p. 413.
} 
cracia representativa.

\section{Democracia representativa e democracia participativa}

Diogo de Figueiredo Moreira Neto alude a um ciclo do poder, o qual englobaria (i) destinação, (ii) atribuição, (iii) exercício, (iv) distribuição, (v) contenção e (vi) detenção. Restringir a democracia ao último momento de referido ciclo acabaria por desvirtuar, se não aniquilar, o seu significado. ${ }^{32}$

Entretanto, embora o fenômeno da democracia participativa encontrese em expansão em todo o mundo, importa ressaltar a importância de conciliá-la com a lógica democrática ainda dominante, ${ }^{33}$ ou seja, a democracia representativa.

Odete Medauar aponta que uma das justificativas para o alargamento da participação administrativa seria a "perda de ascendência, de fato, do Legislativo sobre o Executivo e a Administração e na dúvida quanto à adequada representação de valores e interesses da população pelos integrantes do Legislativo". ${ }^{44}$ Entretanto, indica a autora que favoravelmente à participação poder-se-ia defender que a mesma permite "aprimoramento da conduta dos parlamentares ante o paralelismo da atuação popular; e pode-se ponderar que se trata de mais um meio de compatibilizar as decisões estatais às aspirações e reais interesses da coletividade" ${ }^{35}$

André Molitor posiciona-se favoravelmente à participação, enfatizando que as práticas participativas, longe de colocarem em risco os sistemas representativos, poderão afastar o peso da burocracia que se encontra em suas bases. ${ }^{36}$

Debruçando-se sobre a problemática, João Baptista Machado conclui que por meio da participação reencontram-se, em convergência, os dois vetores da democraticidade, "um que vai buscar a sua origem ao sufrágio político universal, outro que procura harmonizar a acção do Estado com os interesses, necessidades e votos expressos pelos grupos sociais organi-

\footnotetext{
${ }^{30}$ Ibid., p. 414

${ }^{31} \mathrm{Id}$.

32 MOREIRA NETO, Diogo Figueiredo. Direito da Participação Política, 1992. p. 7.

33 "Se, por um lado, tal debate foi resolvido em favor da desejabilidade da democracia como forma de governo, por outro lado, a proposta que se tornou hegemônica ao final das duas guerras mundiais implicou em uma restrição das formas de participação e soberania ampliadas em favor de um consenso em torno de um procedimento eleitoral para a formação de governos (SCHUMPETER, 1942). Essa foi a forma hegemônica de prática da democracia no pós-guerra, em particular nos países que se tornaram democráticos após a segunda onda de democratização" (AVRITZER, Leonardo; SANTOS, Boaventura de Sousa. Introdução: para Ampliar o Cânone Democrático. In: SANTOS, Boaventura de Sousa (Org.). Democratizar a Democracia: os Caminhos da Democracia Participativa. Rio de Janeiro: Civilização Brasileira, 2002. p. 39-82. p. 39-40.)

${ }^{34}$ MEDAUAR, Odete. O Direito Administrativo em Evolução. 2. ed., 2003. p. 233.

${ }^{35} \mathrm{Id}$.

${ }^{36}$ MOLITOR, André. Prefácio. In: DELPEREE, Francis (Org.). Citoyen et Administration. Bruxelas: Bruylant, 1985. p. 11-17. p. 17.
}

A \& C R. de Dir. Administrativo e Constitucional, Belo Horizonte, ano 5, n. 20, p. 167-194, abr.jun. 2005 
zados e activos através dos quais uma sociedade pluralista se manifesta". ${ }^{37}$

É Boaventura de Souza Santos quem apresenta soluções para o que denomina problema democrático: a (necessária) compatibilização em um determinado país da democracia representativa com a democracia participativa.

A primeira solução é a que admite a coexistência entre as duas espécies democráticas: a democracia representativa em nível nacional, convivendo com a democracia participativa em nível local.

A segunda solução seria a complementaridade, que expressaria uma articulação mais intensa entre as duas espécies de democracia. Aqui pressupõe-se que o governo reconheça ser possível a substituição de parte do processo de representação e deliberação típicos da democracia representativa por mecanismos e procedimentos típicos da democracia participativa (v.g. formas públicas de monitoramento, processos de deliberação pública). O objetivo da complementariedade, para o autor, é "associar ao processo de fortalecimento da democracia local formas de renovação cultural ligadas a uma nova institucionalidade política que recoloca na pauta democrática as questões da pluralidade cultural e da necessidade de inclusão social". ${ }^{38}$ Prossegue, esclarecendo que a complementariedade seria diferente da coexistência, pois "implica uma decisão da sociedade política de ampliar a participação em nível local através da transferência ou devolução para formas participativas de deliberação de prerrogativas decisórias a princípio detidas pelos governantes". ${ }^{39}$

Para Boaventura de Souza Santos, enquanto a coexistência da democracia representativa com a participativa prevaleceria nos países centrais, a complementariedade entre ambas emergiria nos países semiperiféricos e periféricos. E arremata, registrando que "é na originalidade das novas formas de experimentação institucional que podem estar os potenciais emancipatórios ainda presentes nas sociedades contemporâneas". ${ }^{40}$

Boaventura de Souza Santos propõe três teses para o fortalecimento da democracia participativa: (i) fortalecimento pela demodiversidade, com a ampliação da deliberação pública e da intensificação da participação, (ii) fortalecimento da articulação contra-hegemônica entre o local e o global, e (iii) ampliação do experimentalismo democrático, no sentido de que as práticas bem sucedidas de participação originam-se em gramá${ }^{37}$ MACHADO, João Baptista. Participação e descentralização, 1982. p. 52.

${ }^{38}$ AVRITZER, Leonardo; SANTOS, Boaventura de Sousa. Introdução: para Ampliar o Cânone Democrático, 2002. p. 76.

39 Id.

40 Ibid., p. 77.

A \& C R. de Dir. Administrativo e Constitucional, Belo Horizonte, ano 5, n. 20, p. 167-194, abr./jun. 2005 
ticas sociais, "nas quais o formato da participação foi sendo adquirido experimentalmente". ${ }^{41}$

Dessarte, passa-se a examinar conceito e características da participação administrativa, com especial destaque para a denominada participação procedimental.

\section{Participação administrativa}

\subsection{Conceituação}

Odete Medauar informa que a participação administrativa é uma técnica retificadora do distanciamento da organização administrativa em relação ao cidadão e à realidade. ${ }^{42}$

Nesse sentido, razão assiste a Mario Nigro quando afirma que por meio da participação "o Estado procura introduzir o mais de sociedade possível em sua esfera, atraindo para o campo do aparato estatal o maior número de interesses sociais e garantindo sua defesa e gestão aos seus titulares, considerados singularmente ou em grupo;...". ${ }^{43}$

Apresentadas suas premissas, é possível definir a participação administrativa como a intervenção individual ou coletiva dos cidadãos na gestão dos órgãos e entidades que integram a Administração pública, com reflexos no conteúdo das decisões deles emanadas. ${ }^{44}$

\subsection{A problemática da participação administrativa}

É João Baptista Machado ${ }^{45}$ quem arrola as principais funções que podem ser atribuídas à participação administrativa.

Em primeiro lugar, aduz que esta se revela uma excelente técnica de canalização e controle dos descontentamentos e frustrações dos cidadãos, facilitando uma melhor integração social e uma maior estabilidade

\footnotetext{
${ }^{41}$ Ibid., p. 78

42 MEDAUAR, Odete. Administração pública ainda sem democracia, 1986. p. 38. Insta registrar a opinião de Caio TÁCITO, para quem "a moderna tendência do direito público marca (...) a transição do Direito Administrativo que, absorvendo a ação participativa dos administrados, valoriza o princípio da cidadania e coloca o indivíduo e a empresa em presença da Administração Pública, como colaboradores privilegiados para a consecução do interesse público" (TÁCITO, Caio. Direito Administrativo Participativo. Revista de Direito Administrativo, Rio de Janeiro, n. 209, p.1-6, jul./set. 1997. p. 6.). Entretanto, cabe salientar o destacado papel de participação das ONGs, não somente nesse processo de estreitamento de laços da população com o Estado, mas principalmente como defensora dos cidadãos em seus pleitos emancipatórios frente ao Estado. Por isso Maria Célia Paoli observa que "o caminho das ONGs opta por representar as demandas populares em negociações pragmáticas, tecnicamente formuladas, com os governos, dispensando a base ampliada da participação popular" (PAOLI, Maria Célia. Empresas e Responsabilidade Social: os Enredamentos da Cidadania no Brasil. In: SANTOS, Boaventura de Sousa (Org.). Democratizar a Democracia: os Caminhos da Democracia Participativa. Rio de Janeiro: Civilização Brasileira, 2002. p. 373-418. p. 378.).

43 NIGRO, Mario. Il nodo della Partecipazione, 1980. p. 230.

${ }^{44}$ Cumpre registrar que participação administrativa, na visão de Diogo Figueiredo Moreira Neto, é espécie do gênero participação política, definida como "a atuação formal e informalmente admitida, dos indivíduos
} 
política. Em seguida, a participação propiciaria o aumento do grau de conscientização dos indivíduos, os quais tornam-se cônscios de seus interesses e de que encontram-se habilitados a promovê-los. Imanente à participação seria o caráter pedagógico, levando ao entendimento de que consiste em "excelente escola de formação cívica, preparando para o exercício da democracia à escala nacional". ${ }^{46}$ Possibilita às autoridades decididoras maior informação sobre as questões que envolvem a satisfação das necessidades coletivas. Confere maior grau de eficácia e efetividade dessas decisões, por refletirem os anseios da coletividade em virtude da intervenção prévia dos cidadãos ou organizações representativas. Isso ensejaria uma maior adesão dos destinatários das decisões administrativas ao seu comando, fazendo desaparecer "a resistência e má-vontade que os administradores em regra manifestam e relativamente às medidas unilaterais da autoridade" ${ }^{47}$ Finalmente, a participação contribuiria enormemente para o aperfeiçoamento da democracia no campo da Administração pública, tornando mais sensível às necessidades e aspirações reais dos cidadãos.

De outro lado, João Baptista Machado elenca problemas ou inconvenientes que eventualmente podem ser enumerados em desfavor da participação administrativa. ${ }^{48}$

Do ponto de vista dos cidadãos, participar significaria empregar tempo e energia nessa atividade, fazendo com que muitos potenciais participantes desistam de assim agir, em virtude do escasso tempo disponível. Uma vez participando, podem considerar tempo perdido as horas em que passaram discutindo os assuntos públicos, se restar claro o rendimento escasso ou nulo dessas situações. Em zonas urbanas e suburbanas não

\footnotetext{
e dos grupos sociais secundários, na ação juspolítica do Estado. Como este, nas organizações políticas contemporâneas, se diversifica em grandes funções e órgãos específicos — os Poderes do Estado —, a participação política se tripartirá em participação legislativa, participação administrativa e participação judiciária,..." (MOREIRA NETO, Diogo Figueiredo. Direito da Participação Política, 1992. p. 56-57.). Cf. GORDILLO, Agustin. Ideas sobre Participación en America Latina. Revista de Direito Público, São Paulo, a.13, n. 57-58, p. 29-38, jan./jun. 1981; GORDILLO, Agustin. La Garantia de Defensa como Principio de Eficacia en el Procedimiento Administrativo. Revista de Direito Público, São Paulo, n. 10, p. 16-24, out./ dez. 1969; e GORDILLO, Agustin. Participación Administrativa. Revista de Direito Público, São Paulo, a. 18, n. 74, p. 15-25, abr./jun. 1985

45 MACHADO, João Baptista. Participação e Descentralização, 1982. p. 37-38.

$46 \mathrm{lbid}$. p. 37. Maria Victoria de Mesquita Benevides destaca que a participação em processos decisórios tem importância de per si, independentemente do resultado do processo, uma vez que "as campanhas que precedem às consultas populares têm uma função informativa e educativa, de valor inegável, tantos para os participantes do lado 'do povo', quanto para os próprios dirigentes e lideranças políticas" (BENEVIDES: Maria Victoria de Mesquita. A cidadania ativa. São Paulo: Ática, 1991. p. 198.)

${ }^{47}$ MACHADO, João Baptista. Participação e Descentralização, 1982. p. 37-38.

${ }^{48}$ Ibid., p. 43-45
}

A \& C R. de Dir. Administrativo e Constitucional, Belo Horizonte, ano 5, n. 20, p. 167-194, abr./jun. 2005 
haveria uma população constante, dificultando o nível de compromisso dessa população na realização coletiva dos objetivos comuns.

Do ponto de vista da Administração pública, a participação tenderia a reduzir a eficiência dos serviços, alargando o processo decisório, além de fomentar a irresponsabilidade dos órgãos de gestão, pois encontrariam nela "uma desculpa fácil para se não comprometerem com uma decisão responsável...". ${ }^{49}$ A participação poderia gerar um excesso de informação para os responsáveis pelas instâncias decisórias, fato que seria contornável pela filtragem do conteúdo dessas informações.

Enfatiza João Baptista Machado que a participação cooptativa participação na execução das decisões visando a facilitar a própria execução - poderia servir o interesse das autoridades, uma vez que implicaria a aceitação dos objetivos globais estabelecidos por outrem. Por derradeiro, o autor registra que favorecer a participação poderia levar ao sacrifício da democracia representativa.

\subsection{Participação administrativa e participação procedimental}

Luís Filipe Colaço Antunes assevera que a participação administrativa teria sua expressão jurídica mais importante na denominada participação procedimental, em que o cidadão participa nas funções levadas a cabo pela Administração pública por intermédio do procedimento de elaboração das decisões administrativas..$^{50}$

Com efeito, visando um melhor conteúdo e eficácia das decisões administrativas cujos efeitos recaiam sobre a população, impende ao poder público dignificar a fase instrutória dos procedimentos a elas correspondentes, ampliando as possibilidades de fornecer e angariar informações úteis, fator essencial ao correto desempenho da função administrativa.

Em primeiro lugar, a adoção de instrumentos participativos enseja uma maior publicidade e transparência no que tange à condução dos assuntos que envolvem a coletividade, concretizando o princípio da publicidade insculpido no caput do art. 37 da Lei Maior. ${ }^{51}$

Em segundo lugar, possibilita aos cidadãos maior e melhor informação e conhecimento sobre as diretrizes dos órgãos administrativos, harmonizando-se com o preconizado no inc. XXXIII do art. $5^{\circ}$ da Constituição da República. Este caráter informativo integra ainda as garantias

\footnotetext{
${ }^{49}$ Ibid., p. 44

50 ANTUNES, Luís Filipe Colaço. A Tutela dos Interesses Difusos em Direito Administrativo. Coimbra: Almedina, 1989. p. 82-83. Cf. NIGRO, Mario. II nodo della Partecipazione, 1980. p. 231-232.
}

A \& C R. de Dir. Administrativo e Constitucional, Belo Horizonte, ano 5, n. 20, p. 167-194, abr.jun. 2005 
constitucionais do contraditório e ampla defesa, previstas no inc. LV do art. $5^{\circ}$ da Carta Magna. Contudo, possível é afirmar que os mecanismos participativos exercem um duplo papel informativo. De um lado, propiciam a obtenção de dados por parte dos cidadãos; de outro, habilitam o órgão administrativo decididor, tornando-o apto a emitir um provimento mais acertado e mais justo, pois estabelece um maior conhecimento acerca da situação subjacente à decisão administrativa.

Em terceiro lugar, o emprego de mecanismos participativos enseja a criação de espaços de efetiva negociação, nos quais as decisões administrativas são tomadas não somente a partir da perspectiva da ponderação ou harmonização dos interesses envolvidos, mas também sob a ótica do que Sabino Cassese denomina reciprocidade de concessões.

O enfoque da negociação significa que Administração pública, empresas, organizações não-governamentais e cidadãos mutuamente cedem sobre pontos relativos ao objeto em discussão, favorecendo a obtenção de um equilíbrio de interesses originalmente contrapostos, que permaneceriam contrapostos se não fosse pela que a ocorrência de trocas e concessões entre as partes. ${ }^{52}$

\subsubsection{Momentos e efeitos da participação procedimental}

Distinguem-se vários níveis de profundidade, ${ }^{53}$ graus de intensidade ou extensãa ${ }^{54}$ dos mecanismos participativos, cujos resultados poderão ser vinculantes ou não-vinculantes para a Administração pública. Tais instrumentos podem ter lugar (i) na fase instrutória (preparatória, informativa ou pré-decisional), (ii) na fase decisória dos procedimentos administrativos e (iii) na fase de execução ou implementação da decisão, sem prejuízo da realização em todas as fases apontadas.

Realizada na fase preparatória, ${ }^{55}$ o objetivo perseguido é o de possibilitar uma ampla instrução do feito. Logo, tem um forte sentido informativo, nos moldes acima especificados. No que concerne aos órgãos públicos,

\footnotetext{
51 Sobre o tema, cf. MARTINS JUNIOR, Wallace Paiva. Transparência Administrativa: Publicidade, Motivação e Participação Popular. São Paulo: Saraiva, 2004.

52 CASSESE, Sabino. La Arena Pública: Nuevos Paradigmas para el Estado. In: La Crisis del Estado. Buenos Aires: Abeledo Perrot, 2003. p. 101-160. O autor assevera que "não é o procedimento que modula a negociação, mas a negociação que plasma o procedimento" (Ibid., p. 157.).

${ }^{53}$ MACHADO, João Baptista. Participação e Descentralização, 1982. p. 41-42. Cf. MOREIRA NETO, Diogo de Figueiredo. Audiências públicas. Revista de Direito Administrativo, Rio de Janeiro, n. 210, p. 11-23, out./dez. 1997.

${ }^{54}$ A extensão da participação não tem por fim evocar a quantidade da participação, e sim a qualidade, a qual segundo Mario Nigro pode partir da cooperação, passar pela co-decisão e chegar até a prevalência da vontade do participante (NIGRO, Mario. Il nodo Della Partecipazione, 1980. p. 232.).
} 
invoca-se ainda o sentido de consulta, decorrente do fato de poder a Administração ouvir previamente os interessados.

Salvo disposição legal em contrário, os resultados da aplicação de instrumentos participativos inseridos nesta fase procedimental não vinculam os órgãos públicos. É que a participação popular levada a efeito teve a finalidade de possibilitar a manifestação de opiniões, propostas e, sobretudo, informar Administração e cidadãos.

Todavia, constatando que os institutos participativos têm lugar, notadamente, no âmbito da atividade administrativa discricionária, eventual posicionamento da população é mais um elemento na limitação da liberdade de atuação da Administração. Ainda que não vinculante, as exposições dos interessados devem ser minuciosamente consideradas pelo órgão decididor, podendo inclusive constituir-se na motivação expressa de sua decisão.

Por outro lado, se inseridos na fase decisória, os resultados obtidos via aplicação de mecanismos participativos será vinculante para a Administração. Todavia, concorda-se com Diogo de Figueiredo Moreira Neto, pois "quando a eficácia pretendida for constitutiva de vontade, gerando uma condição vinculatória, estar-se-á introduzindo um órgão popular de decisão e uma nova função orgânica no sistema existente da administração pública, comprometendo-se, em conseqüência, o exercício de função similar por órgão regular da estrutura do Poder Executivo". ${ }^{56}$

Ainda segundo Diogo de Figueiredo Moreira Neto, a instituição de audiências públicas (um dos instrumentos participativos possíveis) com essa finalidade deve ser feita por lei, "de competência privativa do Poder

\footnotetext{
${ }^{55}$ A Lei federal n 9.784, de 29.01.99, a qual regula o processo administrativo no âmbito da Administração pública federal, estabelece como mecanismos participativos explícitos a consulta pública (art. 31) e a audiência pública (art. 32). Por seu turno, o art. 33 estatui que "os órgãos e entidades administrativas, em matéria relevante, poderão estabelecer outros meios de participação de administrados, diretamente ou por meio de organizações e associações legalmente reconhecidas". Importante observar que a Lei federal n 9.784/99 inseriu os instrumentos de participação administrativa unicamente na fase preparatória ou instrutória do processo administrativo, deixando claro que tais mecanismos devem ser empregados em período anterior à tomada da decisão administrativa. Entretanto, para tornar efetiva a democracia participativa no Brasil seria imprescindível inserir - por meio de expressas previsões legais - estes e outros mecanismos participativos também na fase decisória dos procedimentos administrativos, cujos resultados teriam efeitos vinculantes para a Administração pública. Isso implicaria a criação da forma participativa denominada cogestão, em que o órgão administrativo seria integrado por representantes do poder público e da sociedade, e as decisões dele emanadas são tomadas em conjunto por todos os seus componentes. Nessa acepção, Vital Moreira alude ao termo co-determinação (MOREIRA, Vital. Auto-regulação Profissional e Administração Pública. Coimbra: Almeida, 1997. p. 57.). Há ainda o fenômeno da co-administração ou administração conjunta, definido por Vital Moreira como "o exercício de tarefas administrativas de forma compartilhada entre uma instância da administração pública (estadual ou não) e os administrados interessados, ou entre instâncias de administrações públicas diferentes (...). São formas de colaboração ou cooperação administrativa" (MOREIRA, Vital. Administração Autónoma e Associações Públicas. Coimbra: Coimbra Ed., 1997. p. 73.).
} 
Executivo que pretender, dessa forma, valer-se da participação do administrado (art. $61, \S 1^{\circ}$, e, da Constituição)". ${ }^{57}$

Finalmente, uma vez integrados na fase de execução, os canais participativos caracterizarão a denominada participação cooptativa, "em que aos administrados são explicados os programas da Administração e esta depois se limitará, no máximo, a aceitar algumas propostas ou sugestões daqueles (...) desde que estas não importem mais do que modificações marginais ou secundárias compatíveis com a estratégia global do Plano da Administração". ${ }^{88}$

Cabe esclarecer que os órgãos públicos estarão compelidos à realização ou à utilização de mecanismos participativos sempre que a lei assim estipular. Entretanto, a Administração estará simplesmente facultada a implementá-la, no caso de não haver previsão expressa para sua realização.

Os efeitos advindos em uma e outra hipótese são distintos.

Assim, desde que obrigatórios, constituir-se-ão em condição de validade do procedimento administrativo em que estiverem inseridos. Caso não implementados, ao arrepio da determinação legal, o procedimento estará viciado, e a decisão administrativa correspondente será passível de invalidação. Por outro lado, estando a Administração meramente facultada a promover tais mecanismos participativos — com as ressalvas de eventuais previsões legislativas em contrário - nenhuma implicação haverá diante da sua não realização.

No entanto, devem ser apreciados os casos em que é conferida legitimidade a interessados (cidadãos ou entidades associativas) para solicitar a realização de instrumentos participativos, previamente à emissão de uma decisão administrativa. Se formulado e deferido pela Administração, a realização ou emprego desse instrumento torna-se obrigatória. Em não sendo utilizado tal mecanismo por responsabilidade da Administração, defende-se que o procedimento correspondente encontrar-se-á maculado, sendo passível de declaração de nulidade o provimento final.

\subsection{Legitimidade pelo procedimento e legitimidade pela participação}

A participação procedimental suscita ainda o tema da legitimidade pelo

\footnotetext{
${ }^{56}$ MOREIRA NETO, Diogo Figueiredo. Direito da Participação Política, 1992. p. 126

$57 \mathrm{Id}$.

58 MACHADO, João Baptista. Participação e Descentralização, 1982. p. 42.
}

A \& C R. de Dir. Administrativo e Constitucional, Belo Horizonte, ano 5, n. 20, p. 167-194, abr./jun. 2005 
procedimento, em que a legitimidade da decisão repousaria nas competências de decisão e na realização dos correspondentes procedimentos, ambos traçados previamente por lei.

José Joaquim Gomes Canotilho posiciona-se desfavoravelmente a essa tese, aduzindo que "não se asseguram decisões informadas por critérios de justiça material só pelo facto de essas decisões terem observado determinados princípios de 'justiça procedimental'...". ${ }^{59}$ Acrescenta o autor que o procedimento não é um fim em si mesmo, "antes desempenha a tarefa de abrir o caminho para soluções intrinsecamente justas". ${ }^{60}$

Niklas Luhmann é apontado como um dos grandes defensores da legitimidade pelo procedimento. Para o autor, a função legitimadora do procedimento não seria a de obter o consenso entre as partes, ou mesmo a justiça das decisões ${ }^{61}$ mas fazer com que as partes aceitem a decisão em de cujo procedimento prévio participaram, em que pesem eventuais decepções e descontentamentos. E sobre o tema da participação cidadã na esfera administrativa, o autor propugna alguns temperamentos no que denomina relações informativas entre a administração e o público: ${ }^{62}$

\footnotetext{
Nos processos de decisão orientados para um objetivo, pode procurar-se, quando muito, mediante a criação de "sistemas de contato", ou mediante uma disposição mais aceitável de meios e compensações, alcançar o consenso e a cooperação mais concretos possíveis entre os interessados. Este esforço não é inofensivo, pois leva a uma considerável restrição das possibilidades de decisão administrativa, obriga à admissão de várias informações e objetivos secundários no decurso da decisão e sobrecarrega a racionalidade da decisão. As pesquisas mais recentes em países em vias de desenvolvimento, em relação com as empresas típicas de prestação de serviços (escolas, hospitais, prisões de orientação "terapêutica", hospícios, etc.) onde a cooperação dos que aí são atendidos é condições de sucesso, mostraram claramente que as organizações têm de ser desburocratizadas, no caso de se lhes querer atribuir uma co-responsabilidade pela orientação do seu público. Sob determinadas condições sociais, ou em determinadas tarefas, isto pode ser indispensável. O que deveria ser válido, sobretudo quando os próprios processos políticos não conseguem suficiente apoio político para a administração, de forma que esta necessita de desempenhar por si mesma funções políticas e organizar, em cada caso, um público cooperante. Com isso se renuncia às vantagens duma diferenciação funcional

${ }^{59}$ CANOTILHO, José Joaquim Gomes. Direito Constitucional. 5. ed. 2. reimp., 1992. p. 117.

60 Ibid. p. 117-118.

${ }^{61}$ Todavia, reconhece que "o núcleo de todas as teorias clássicas do procedimento é a relação com a verdade ou com a verdadeira justiça como objetivo" (LUHMANN, Niklas. Legitimação pelo Procedimento. Brasília: UnB, 1980. p. 21.). Entendendo que a justiça é uma das finalidades do processo administrativo, cf. MEDAUAR, Odete. A Processualidade no Direito Administrativo. São Paulo: Revista dos Tribunais, 1993. p. 66-67.

62 LUHMANN, Niklas. Legitimação pelo Procedimento, 1980. p. 171.
}

A \& C R. de Dir. Administrativo e Constitucional, Belo Horizonte, ano 5, n. 20, p. 167-194, abr.jun. 2005 
de política e administração. Em resumo: a administração burocrática, que está equipada com meios financeiros necessários e conforme às competências e é sempre independente do consenso dos interessados, deveria ser mais eficaz, pois sua forma de trabalho pode ser gravada de forma conseqüente e específico-funcional para a adaptação de certos programas de decisão. A sua racionalidade e eficácia convertem-se, então, em fator de apoio de legitimação (política) do sistema administrativo como um todo. Permite escolher entre diversas alternativas e propor à administração mais programas de objetivos do que quando a cooperação dos mais interessados na ocasião tinha de ser assegurada concretamente e sob a forma de permuta. Aquela complexidade maior e liberdade de decisão na administração perder-se-ia, se se quisesse retirar à administração a co-responsabilidade política pela adoção bem-intencionada das suas decisões através do público. Na medida em que a política desempenha essa função, a administração pode ser aliviada da própria conservação política com o consenso. ${ }^{63}$

Em que pese a opinião acima reproduzida, entende-se que mais do que uma tendência da Administração pública contemporânea, a participação administrativa é uma realidade e há de ser entronizada no corpo administrativo do Estado.

No entanto, para serem considerados mecanismos cooperativos úteis, tudo aquilo que for discutido ou configurar resultado do emprego de instrumentos participativos (v.g. audiências pública, consultas públicas, referendos administrativos, coletas de informação, entre outros) deve ser devidamente considerado pelo órgão ou autoridade decididora, previamente à emissão do provimento administrativo.

Assim, a concordância ou aderência dos cidadãos aos provimentos emitidos pelos centros decisórios administrativos será uma conseqüência da maior legitimidade dessa decisão, pois seus pleitos, opiniões e sugestões foram ao menos apreciados. Isso acarretará maior eficácia e efetividade das decisões administrativas, sendo o caso de defender-se hodiernamente

\footnotetext{
63 Ibid., p. 168-169. Nessa passagem, o autor deixa transparecer que a legitimação da função administrativa concentrar-se-ia no aspecto da tomada da decisão pela via do procedimento, e portanto, sob a ótica da produção ou geração dos efeitos da ação administrativa (eficácia). E embora seja possível afirmar que grande parte da ação administrativa prescinda do assentimento ou da concordância de seus destinatários para que se encontre apta a produzir efeitos, cabe notar que o critério da justiça dessas decisões não é totalmente alcançado simplesmente pela realização do procedimento. Assim, e principalmente diante de um modelo gerencialista de gestão pública, importa cada vez mais indagar-se sobre meios e formas de atingir-se a justiça das decisões emanadas da Administração públiça. E a justiça pode vir a ser conquistada por meio da efetivação do direito de participação administrativa. É o caso, portanto, de concordar-se com Adriana da Costa Ricardo Schier, para quem no contexto assinalado, "o direito de participação do cidadão no âmbito da Administração Pública torna-se um instrumento central porque permite a legitimação das atividades administrativas. Com efeito, a legitimidade dos atos administrativos deixa de ser legal e passa a ser conferida pelo resultado eficiente, obtido, principalmente, através da participação do cidadão na esfera pública, seja mediante a interferência nos processos decisórios, seja mediante a fiscalização,..." (SCHIER, Adriana da Costa Ricardo. A Participação Popular na Administração Pública: o Direito de Reclamação. Rio de Janeiro: Renovar, 2002. p. 251-252.).
} 
a legitimidade pela participação, inclusive como meio de obter-se maior eficiência no desempenho da função administrativa e maior justiça da decisão administrativa. ${ }^{64}$

Nesse passo, insta observar que a junção da noção de democracia à de Estado de direito, muito mais do que estabelecer um qualificativo do modo de ser do Estado, é responsável pela atribuição aos cidadãos do direito de participação nas decisões estatais. ${ }^{65}$

A Constituição Espanhola de 1978, considerada uma das grandes referências contemporâneas em matéria de reconhecimento, proteção e incentivo à participação popular, faz referência expressa ao direito de participação nas decisões estatais em ao menos três momentos. $\mathrm{O}$ art. 9.2 estabelece, como um dos princípios constitucionais basilares, corresponder aos poderes públicos facilitar a participação de todos os cidadãos na vida política, econômica, cultural e social. Qualificando-o como um direito fundamental, estatui o art. 23.1 que os cidadãos têm o direito de participar nos assuntos públicos, diretamente ou por meio de representantes. Por seu turno, o art. 105 (a) reza que a lei regulará a audiência dos cidadãos, diretamente ou através das organizações e associações reconhecidas por lei, no procedimento de elaboração das disposições administrativas que os afetem.

A Constituição Brasileira estabelece no par. único do art. $1^{\circ}$ que "todo o poder emana do povo, que o exerce por meio de representantes eleitos ou diretamente, nos termos desta Constituição". Exemplificando, cumpre registrar que, sinalizando o caminho da colaboração entre Administração e população, a Lei Maior admite no inc. X do art. 29 "a coo-

\footnotetext{
${ }^{64}$ Rogério Gesta LEAL propõe a construção de uma gestão pública compartida, incentivando a criação de instrumentos de co-participação na administração dos interesses públicos, além de procedimentos de interlocução permanentes entre os atingidos e interessados pelas políticas públicas. Isso implicaria, na visão do autor, reconhecer "que tanto é preciso ampliar os espaços de participação material do cidadão na gestão pública, como aquilitar os já existentes..." (LEAL, Rogério Gesta. Gestão Pública Compartida: Construtos Epistemológicos. A\&C Revista de Direito Administrativo e Constitucional, Belo Horizonte, a. 3, n. 12, p. 87111, abr./jun. 2003. p. 109.).

${ }^{65}$ Maria Sylvia Zanella Di Pietro afirma ser a participação popular na Administração Pública "uma característica essencial do Estado de Direito Democrático, porque ela aproxima mais o particular da Administração, diminuindo ainda mais as barreiras entre o Estado e a sociedade" (DI PIETRO, Maria Sylvia Zanella. Participação Popular na Administração Pública. Revista de Direito Administrativo, Rio de Janeiro, v. 191, p. 26-39, jan./ mar. 1993, p. 32.). Elencando formas de atuação direta (direito de ser ouvido, enquete) e indireta (participação popular em órgãos de consulta e de decisão, por meio do ombudsman e por via do Poder Judiciário), a autora aduz que a atuação dos cidadãos deve ocorrer diretamente na gestão e no controle da Administração pública (Ibid., p. 38.). Adriana da Costa Ricardo Schier sustenta que o direito de participação no âmbito administrativo é um meio de democratização da esfera do poder público, determinando uma maior contribuição dos cidadãos na tomada das decisões estatais (SCHIER, Adriana da Costa Ricardo. A Participação Popular na Administração Pública, 2002. p. 74.). Especificamente sobre o tema, cf. SOARES, Fabiana de Menezes. Direito Administrativo de Participação. Belo Horizonte: Del Rey, 1997.
} 
peração das associações representativas no planejamento municipal", concretizando-se, por exemplo, na idealização do plano diretor (art. 182 e seguintes). Por seu turno, o inc. VII do parágrafo único do art. 194 possibilita uma gestão democrática e descentralizada da seguridade social, "com a participação da comunidade, em especial de trabalhadores, empresários e aposentados". Gestões similares estão previstas no inc. III do art. 198 (saúde), inc. II do art. 204, (assistência social) e inc. VI do art. 206 (ensino público). A conservação do patrimônio cultural brasileiro deve ser promovida com a cooperação da comunidade ( $\$ 1^{\circ}$ do art. 216$)$, e a tutela do meio ambiente (bem de uso comum do povo) há de ser levada a efeito com a participação da comunidade (caput do art. 225), sendo dever do Estado a promoção da educação ambiental e da conscientização pública para o fim aludido (inc. VI do art. 225).

Eduardo García de Enterría e Tomás-Ramón Fernández apresentam três justificativas para o fomento ao exercício da participação popular na Administração pública.

Primeiramente, a consciência da necessária aproximação do poder com a sociedade, em substituição à separação antes dominante, e que servira de base à construção liberal. Em segundo lugar, a exigência de afastar os riscos que um governo dominado por burocratas pode gerar para a sociedade, tornando possível a identidade entre governantes e governados. E em terceiro lugar, considerando ser a ideologia participativa um autêntico contraponto ao desenvolvimento dos sistemas burocráticos, os autores defendem que a Administração participada ou concertada é uma técnica essencial de eficiência, a qual visaria complementar ou substituir a tradicional Administração autoritária.

De acordo com os autores, "a idéia de participação dos administrados nos processos de decisão parece capaz não somente de diminuir as disfunções organizativas e burocráticas, mas também de obter um novo consensus, uma nova legitimidade (...) que permita superar a atual crise do poder autoritário...". ${ }^{66}$

\subsection{Participação, descentralização e negociação}

Miguel Sanchez Moron aduz que para propiciar a efetividade do princípio participativo seria necessário tomar medidas de ordem jurídica e institucional, tornando o aparelho administrativo (i) menos burocrático, 
(ii) menos autocentrado, (iii) mais aberto às demandas sociais e (iv) mais próximo dos cidadãos. Ao lado disso, destaca a relevância de dois aspectos essenciais ao tema da participação administrativa. O primeiro diz respeito à melhoria do acesso da informação do público sobre a ação administrativa; o segundo, ao aumento da descentralização da organização pública. ${ }^{67}$

No mesmo sentido, João Baptista Machado enfatiza a estreita relação entre participação e descentralização, ${ }^{68}$ afirmando que "a descentralização cria, pois, quadros adequados ao desenvolvimento de fórmulas de "participação’ das populações na vida pública". ${ }^{69}$

Contudo, após estabelecer as distinções entre participação e descentralização, ${ }^{70} \mathrm{o}$ autor sustenta que ambas estão interligadas a um outro fenômeno: a negociação:

Assentemos pois em que o reconhecimento de qualquer direito de participação é do mesmo passo reconhecimento de autonomia: de uma autonomia mais ou menos pronunciada, certo, mas em todo o caso suficiente para justificar um desvio de "temperamento" a um princípio maioritário de escalão mais amplo. $\mathrm{E}$, ao mesmo tempo, tenhamos presente que o pressuposto das soluções negociadas - da "concertação" - é uma certa "descentralização" de funções. É esta "descentralização", e o reconhecimento da correspondente autonomia aos corpos sociais que dela beneficiam, que engendra um espaço de negociação e que permite, portanto, substituir o regime das soluções negociadas ao das decisões unilateralmente impostas. ${ }^{71}$

E continua João Baptista Machado, explicitando sua afirmação:

Salientemos mais uma vez esta conclusão que se extrai de tudo o exposto: a "descentralização" engendra um espaço de participação e de negociação que, dando voz e peso às diversas autonomias sociais, opões uma barreira ao totalitarismo das maiorias (à "autocracia electiva") e torna a democracia mais rica e mais humana, impedindo a "estatização". Descentralização é, com efeito, o outro nome da liberdade. Representando, nas suas múltiplas manifestações, princípios organizativos da acção diferentes dos do Estado, em círculos cada vez mais convi-

\footnotetext{
${ }^{66}$ FERNÁNDEZ, Tomás-Ramón; GARCÍA DE ENTERRÍA, Eduardo. Curso de Derecho Administrativo. 6. ed. Madrid: Civitas, 1999 , v. 2, p. 84

${ }^{67}$ SANCHEZ MORON, Miguel. Espagne. In: DELPEREE, Francis (Org.). Citoyen et Administration, 1985. p. 71

68 Para Celso Antônio Bandeira de Melo, descentralização administrativa "é um sistema técnico-administrativo, através do qual o desempenho das funções pertinentes à Administração se processa através de vários organismos que desfrutam de largo grau de independência" (BANDEIRA DE MELLO, Celso Antônio. Natureza e Regime Jurídico das Autarquias. São Paulo: Revista dos Tribunais, 1968. p. 29.)

${ }^{69}$ MACHADO, João Baptista. Participação e Descentralização, 1982. p. 55. Odete Medauar assinala que "em vários países europeus associou-se a descentralização (sobretudo a territorial) à participação, para que as instâncias de decisão se tornassem menos distantes dos cidadãos". (MEDAUAR, Odete. O Direito Administrativo em Evolução. 2. ed., 2003. p. 235.).

${ }^{70}$ MACHADO, João Baptista. Participação e Descentralização, 1982. p. 55-56.

${ }^{71}$ Ibid., p. 56.
}

A \& C R. de Dir. Administrativo e Constitucional, Belo Horizonte, ano 5, n. 20, p. 167-194, abr.jun. 2005 
zinhos da pessoa do cidadão e indo até o reconhecimento da autonomia pessoal deste, ela garante aquela interacção dialéctica capaz de impedir que o mesmo Estado se produza a si próprio, que a massa dos cidadãos funcione, através das eleições políticas, como simples "transductor" de forças que, engendradas pelo enquadramento estatal, a ele regressam sob a aparência de uma legitimação formal mas profundamente inautêntica. ${ }^{72}$

Em sentido aproximado, jungindo negociação à participação administrativa, afirma Luciano Parejo Alfonso:

Mesmo no plano da atuação administrativa, a própria Administração, com sua forma de fazer (seu "estilo" de atuar) gera pautas e critérios. Aqui é grande o fator da aceitação, cooperação e consenso para conquistar a conformação da conduta dos cidadãos. Ainda que a conformidade de uma decisão administrativa ao Direito não dependa em sentido estrito de sua aceitação social, deve-se considerar correta a interpretação de sua busca como um mandamento constitucional implícito. Nesse contexto, entende-se a importância da participação cidadã na atuação administrativa. Por mais que deva-se ter em conta o perigo que a participação possa representar para o Estado de Direito, a decantação progressiva do Estado - em suas relações com o cidadão - em direção ao modelo cooperativo, o qual procura o compromisso por meio da negociação e da formação do consenso, obriga-o nesse campo a uma estratégia nem um pouco evasiva, promovendo-se a melhoria das fórmulas de participação. Justamente nesse ponto resultam importantes os critérios procedimentais administrativos para a facilitação da inovação, concretamente no que diz respeito à exploração das possibilidades da atuação informal (contatos, conversas), a audiência e a decisão acordada ou convencionada. ${ }^{73}$

\subsection{A participação gerencial}

Cabe apontar ainda a opinião de Marco Aurélio Nogueira, autor que coloca em relevo a participação gerencial, identificada como "um outro tipo de participação que se orienta por uma idéia de política como 'troca' entre governantes e governados: quanto mais interações cooperativas existirem, melhor para o sucesso eleitoral e a legitimação dos governantes e melhor para os grupos sociais envolvidos, que podem assim ver atendida parte de suas postulações". ${ }^{74}$ [sem grifo no original]

Consoante o autor, a participação gerencial pode (i) facilitar a obtenção de respostas para as demandas comunitárias, (ii) ampliar a comunicação entre governantes e governados, (iii) fornecer melhores parâmetros para a tomada de decisões e (iv) fortalecer a gestão pública e 72 Ibid., p. 64-65.

73 PAREJO ALFONSO, Luciano. La Terminación Convencional del Procedimiento Administrativo como forma Alternativa de Desarrollo de la Actividad Unilateral de la Administración. In: Tres Estudios. Madrid: INAP, 1995. p. 153-213. p. 162. . Eficacia y Administración: 
promover a expansão da cidadania ativa. ${ }^{75}$

\section{Considerações finais}

No processo de transformação do Estado contemporâneo, desponta a função estatal de mediação, revelando que incumbência estatal passa a ser não somente a de estabelecer e de conferir eficácia aos canais de participação e interlocução com os indivíduos e grupos sociais, mas a de com eles constantemente interagir, com o escopo especial de instituir e manter vínculos. Tais vínculos são cada vez mais necessários para atribuir eficácia, eficiência e efetividade às ações estatais no atual âmbito das relações e interseções entre Estado e sociedade civil, esferas em crescente processo de recíproca interpenetração.

Com efeito, vem ganhando prestígio mundial a discussão acerca de uma cultura do diálogo, em que o Estado há de conformar suas ações em face das emanações da diversidade social..$^{76}$ Alude-se à figura de um Estado "que conduz sua ação pública segundo outros princípios, favorecendo o diálogo da sociedade consigo mesma". ${ }^{77}$

Nesse sentido, Joan Prats I Catalá alude a uma mudança paradigmática do direito administrativo, a partir (i) do desenvolvimento de teorias e técnicas de construção e gestão de redes interorganizativas, (ii) do incremento do interesse pelas relações interadministrativas, (iii) do manejo da gestão pública sob a orientação de diferentes formas convencionais ou participativas, distintas do ato administrativo tradicional, e (iv) do desenvolvimento do posicionamento jurídico do cidadão perante os serviços públicos a serem prestados. ${ }^{78}$

Por tais razões, buscou-se nesse trabalho estabelecer as linhas basilares, o conteúdo e os efeitos da participação administrativa, genericamente entendida como a possibilidade de intervenção popular na gestão dos assuntos que dizem respeito a toda a coletividade, com reflexos na determinação do conteúdo da decisão administrativa.

A participação administrativa caracteriza-se como um dos mais

\footnotetext{
${ }^{74}$ NOGUEIRA, Marco Aurélio. Gestão Participativa, Estado e Democracia. In: Um Estado para a Sociedade Civil: Temas Éticos e Políticos da Gestão Democrática. São Paulo: $\overline{C o r t e z}, 2004$. p. 117-166. p. 142.

75 Ibid., p. 142-143.

${ }^{76}$ BELLOUBET-FRIER, Nicole; TIMSIT, Gérard. L'administration en chantiers. Revue du Droit Public et de la Science Politique en France et a l'étranger, Paris, n. 2, p. 299-324, avr. 1994. p. 303.

77 Ibid., p. 314.
}

A \& C R. de Dir. Administrativo e Constitucional, Belo Horizonte, ano 5, n. 20, p. 167-194, abr.jun. 2005 
importantes temas relacionados ao direito administrativo prospectivo, ramo jurídico que se encontra em constante evolução, sobretudo para fazer frente às relações e interseções contemporâneas mantidas entre Estado, Administração pública e sociedade civil.

Nesse quadro, aponta-se para o surgimento de uma nova concepção de Administração pública, a Administração pública dialógica, a qual contrasta com a tradicional Administração pública monológica, refratária à instituição e ao desenvolvimento de processos comunicacionais com a sociedade.

Assim, importa ao Estado contemporâneo reforçar os vínculos com a sociedade civil, habilitando a organização administrativa para bem corresponder ao desafio de potencializar os efeitos positivos que a experiência com instrumentos participativos pode acarretar no desenvolvimento das ações estatais.

\section{Bibliografia}

AMARAL, Diogo Freitas do. Curso de Direito Administrativo. 2. ed. 5. reimp. Coimbra: Almedina, 2001. v. 1.

ANTUNES, Luís Filipe Colaço. A Tutela dos Interesses Difusos em Direito Administrativo. Coimbra: Almedina, 1989.

AVRITZER, Leonardo; SANTOS, Boaventura de Sousa. Introdução: para Ampliar o Cânone Democrático. In: SANTOS, Boaventura de Sousa (Org.). Democratizar a Democracia: os Caminhos da Democracia Participativa. Rio de Janeiro: Civilização Brasileira, 2002. p. 39-82.

BANDEIRA DE MELLO, Celso Antônio. Natureza e Regime Jurídico das Autarquias. São Paulo: Revista dos Tribunais, 1968.

BELLOUBET-FRIER, Nicole; TIMSIT, Gérard. Ladministration en Chantiers. Revue du Droit Public et de la Science Politique en France et a l'étranger, Paris, n. 2, p. 299-324, avr. 1994.

BENEVIDES: Maria Victoria de Mesquita. A Cidadania Ativa. São Paulo: Ática, 1991.

BOBBIO, Norberto et al. Crisis de la Democracia. Barcelona: Editorial Ariel, 1985.

. Estado, Governo e Sociedade. 4. ed. Rio de Janeiro: Paz e Terra, 1987.

. O Futuro da Democracia: uma Defesa das Regras do Jogo. 5. ed. Rio de Janeiro: Paz e Terra, 1992.

BONAVIDES, Paulo. Ciência Política. 10. ed. São Paulo: Malheiros, 2003.

CAEtano, Marcelo. Tendências do Direito Administrativo Europeu. Revista de Direito Público. São Paulo, n. 1, p. 25-39, jul./set. 1967.

78 PRATS I CATALÁ, Joan. Direito e Gerenciamento nas Administrações Públicas: Notas sobre a Crise e Renovação dos Respectivos Paradigmas. Revista do Serviço Público, Brasilia, a. 47, v. 120, n. 2, p. $23-46$. maio/ago. 1996. p. 40.

A \& C R. de Dir. Administrativo e Constitucional, Belo Horizonte, ano 5, n. 20, p. 167-194, abr.jun. 2005 
CANOTILHO, José Joaquim Gomes. Direito Constitucional. 5. ed. 2. reimp. Coimbra: Almedina, 1992.

CASSESE, Sabino. La Arena Pública: Nuevos Paradigmas para el Estado. In: . La Crisis del Estado. Buenos Aires: Abeledo Perrot, 2003. p. 101-160.

CLÈVE, Clèmerson Merlin. O Cidadão, a Administração Pública e a Nova Constituição. Revista de Informação Legislativa, Brasília, a. 27, n. 106, p. 81-98, abr.jun. 1990.

COMPARATO, Fábio Konder. A Nova Cidadania. In: . Direito Público: Estudos e Pareceres. São Paulo: Saraiva, 1996, p. 3-24.

DELPEREE, Francis (Org.). Citoyen et Administration. Bruxelas: Bruylant, 1985.

DI PIETRO, Maria Sylvia Zanella. Participação Popular na Administração Pública. Revista de Direito Administrativo, Rio de Janeiro, v. 191, p. 26-39, jan./mar. 1993.

FAZZALARI, Elio. Processo: Teoria Generale. In: NOVISSIMO Digesto Italiano. S.l.: s.n., 1966, v. 13.

FERNÁNDEZ, Tomás-Ramón; GARCÍA DE ENTERRÍA, Eduardo. Curso de Derecho Administrativo. 6. ed. Madrid: Civitas, 1999, v. 2.

FERRARI, Regina Maria Macedo Nery. Participação Democrática: Audiências Públicas. In: CUNHA, Sérgio Sérvulo; GRAU, Eros Roberto (Org.) Estudos de Direito Constitucional em Homenagem a José Afonso da Silva. São Paulo: Malheiros, 2003. p. 325-351.

FERREIRA FILHO, Manoel Gonçalves. Comentários à Constituição Brasileira de 1988. 3. ed. São Paulo: Saraiva, 2000. v. 1.

GABARDO, Emerson. Eficiência e Legitimidade do Estado: uma Análise das Estruturas Simbólicas do Direito Político. Barueri: Manole, 2003.

GORDILLO, Agustin. Ideas sobre Participación en America Latina. Revista de Direito Público, São Paulo, a.13, n. 57-58, p. 29-38, jan./jun. 1981.

La Garantia de Defensa como Principio de Eficacia en el Procedimiento Administrativo. Revista de Direito Público, São Paulo, n. 10, p. 16-24, out./dez. 1969.

. Participación Administativa, Revista de Direito Público, São Paulo, a. 18, n. 74, p. 15-

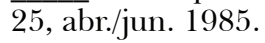

LEAL, Rogério Gesta. Gestão Pública Compartida: Construtos Epistemológicos. AEC Revista de Direito Administrativo e Constitucional, Belo Horizonte, a. 3, n. 12, p. 87-111, abr.jun. 2003.

LUHMANN, Niklas. Legitimação pelo Procedimento. Brasília: Universidade de Brasília, 1980.

MACHADO, João Baptista. Participação e Descentralização: Democratização e Neutralidade na Constituição de 76. Coimbra: Almedina, 1982.

MARTINS JUNIOR, Wallace Paiva. Transparência Administrativa: Publicidade, Motivação e Participação Popular. São Paulo: Saraiva, 2004.

MEDAUAR, Odete. A Processualidade no Direito Administrativo. São Paulo: Revista dos Tribunais, 1993.

. Administração Pública ainda sem Democracia. Problemas Brasileiros, São Paulo, a. 23, n. 256 , p. 37-53., mar./abr. 1986.

. O Direito Administrativo em Evolução. 2. ed. São Paulo: Revista dos Tribunais, 2003.

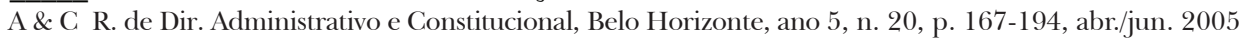


MIRANDA, Jorge. Textos Históricos do Direito Constitucional. 2. ed. Lisboa: Imprensa Nacional, 1990 .

MOLITOR, André. Prefácio. In: DELPEREE, Francis (Org.). Citoyen et Administration. Bruxelas: Bruylant, 1985. p. 11-17.

MOREIRA NETO, Diogo de Figueiredo. Apontamentos sobre a Reforma Administrativa. Rio de Janeiro: Renovar, 1999.

. Audiências Públicas. Revista de Direito Administrativo, Rio de Janeiro, n. 210, p. 1123, out./dez. 1997.

. Direito da Participação Política. Rio de Janeiro: Renovar, 1992.

MOREIRA, Vital. Administração Autónoma e Associações Públicas. Coimbra: Coimbra, 1997.

. Auto-regulação Profissional e Administração Pública. Coimbra: Almeida, 1997.

NIGRO, Mario. Il nodo della Partecipazione. Rivista Trimestrale di Diritto e Procedura Civile, Milão, a. 34, n. 1, p. 225-236, mar. 1980.

NOGUEIRA, Marco Aurélio. Gestão Participativa, Estado e Democracia. In: .Um Estado para a Sociedade Civil: Temas Éticos e Políticos da Gestão Democrática. São Paulo: Cortez, 2004. p. 117-166.

OLIVEIRA, Gustavo Henrique Justino de. As Audiências Públicas e o Processo Administrativo Brasileiro. Revista de Direito Administrativo, Rio de Janeiro, n. 209, p. 153-167, jul./set. 1997.

ORTIZ DIAS, José. El Horizonte de las Administraciones Públicas en el Cambio de Siglo: Algunas Consideraciones de Cara al Año 2000. In: SOSA WAGNER, Francisco (Coord.) El Derecho Administrativo en el Umbral del Siglo XXI: Homenage al Profesor Dr. D. Ramón Martín Mateo. Valencia: Tirant lo Blanch, 2000. t. 1, p. 63-117.

PAOLI, Maria Célia. Empresas e Responsabilidade Social: os Enredamentos da Cidadania no Brasil. In: SANTOS, Boaventura de Sousa (Org.). Democratizar a Democracia: os Caminhos da Democracia Participativa. Rio de Janeiro: Civilização Brasileira, 2002. p. 373-418.

PAREJO ALFONSO, Luciano. La Terminación Convencional del Procedimiento Administrativo como Forma Alternativa de Desarrollo de la Actividad Unilateral de la Administración. In: Eficacia y Administración: tres Estudios. Madrid: INAP, 1995. p. 153-213.

PINSKY, Jaime. Introdução. In: PINSKY, CARLA Bassanezi; PINSKY, Jaime (Orgs.). História da Cidadania. São Paulo: Contexto, 2003. p. 9-13.

PRATS I CATALÁ, Joan. Direito e Gerenciamento nas Administrações Públicas: Notas sobre a Crise e Renovação dos Respectivos Paradigmas. Revista do Serviço Público, Brasilia, a. 47, v. 120, n. 2, p. 23- 46. maiO/ago. 1996.

RODRÍGUEZ GUERRA, Jorge. Capitalismo Flexible y Estado de Bienestar. Granada: Comares, 2001.

SAMPAIO, José Adércio Leite. Democracia, Constituição e Realidade. Revista Latinoamericana de Estudos Constitucionais, Belo Horizonte, n.1, p. 741-823, jan./jun. 2003.

SCHIER, Adriana da Costa Ricardo. A Participação Popular na Administração Pública: o Direito de Reclamação. Rio de Janeiro: Renovar, 2002.

A \& C R. de Dir. Administrativo e Constitucional, Belo Horizonte, ano 5, n. 20, p. 167-194, abr.jun. 2005 
SOARES, Fabiana de Menezes. Direito Administrativo de Participação. Belo Horizonte: Del Rey, 1997.

TÁCITO, Caio. Direito Administrativo Participativo. Revista de Direito Administrativo, Rio de Janeiro, n. 209, p.1-6, jul./set. 1997.

VIEIRA, Liszt. Cidadania e Globalização. 6. ed. Rio de Janeiro: Record, 2002.

VILLORIA MENDIETA, Manuel. La Modernización de la Administración como Instrumento al Servicio de la Democracia. Madrid: Inap, 1996.

WILSON, Woodrow. O Estudo da Administração. Cadernos de Administração Pública, Rio de Janeiro, n. 16, p. 1-35, 1955.

Informação bibliográfica deste texto, conforme a NBR 6023:2002 da Associação Brasileira de Normas Técnicas (ABNT):

OLIVEIRA, Gustavo Henrique Justino de. Participação Administrativa. AE $\mathcal{E}^{2}$ C Revista de Direito Administrativo e Constitucional, Belo Horizonte, ano 5, n. 20, p. 167-194, abr./jun. 2005. 